\title{
レーザーマイクロダイセクション法を用いた凍結切片からの遺伝子発現解析
}

\author{
朝比奈雅志 ${ }^{1,2}$, 中野渡幸 ${ }^{1}$, 山田一貴 ${ }^{1}$, 湯本絵美 $^{2}$, 佐藤忍 $^{3}$ \\ 1 帝京大学理工学部バイオサイエンス学科％320-8551 栃木県宇都宮市豊郷台 1-1 \\ 2 帝京大学先端機器分析センター †320-8551 栃木県宇都宮市豊郷台 1-1 \\ 3 筑波大学生命環境系 $=305-8572$ 茨城県つくば市天王台1-1-1
}

要旨：レーザーマイクロダイセクション (Laser Microdissection; LMD) 法は，顕微鏡とレーザー照射装置が接続された 機器を用いて，切片を観察しながら標的細胞・組織をレーザーで切断して対象領域を回収する方法であり，組織特異 的な遺伝子発現解析などに活用されている。 LMD 法はこれまでに動物組織を中心に多くの研究成果が報告されてき たが，植物においても，LMD を応用した様々な研究成果が報告されるようになっている。近年，LMDによって回収 した組織は, 遺伝子発現解析の他, DNA, タンパク質, 代謝産物なぞ, 様々な解析への適用が実現しており, 細胞・ 組織レベルでの時空間的定量解析が可能となっている。本稿では，我々が用いているレーザーマイクロダイセクショ ンを用いた植物凍結切片からの組織回収と遺伝子解析，植物ホルモン分析の概略について紹介する。

\section{Spatio-temporal gene expression analysis from cryosection using laser microdissection}

\author{
Masashi Asahina $^{1,2}$, Miyuki Nakanowatari ${ }^{1}$, Kazuki Yamada $^{1}$, Emi Yumoto $^{2}$, Shinobu Satoh $^{3}$ \\ ${ }^{1}$ Department of Biosciences, Teikyo University. 1-1 Toyosatodai, Utsunomiya, Tochigi, 320-8551, Japan \\ ${ }^{2}$ Advanced Instrumental Analysis Center, Teikyo University. 1-1 Toyosatodai, Utsunomiya, Tochigi, 320-8551, Japan \\ ${ }^{3}$ Faculty of Life and Environmental Sciences, University of Tsukuba. 1-1-1 Tennoudai, Tsukuba, Ibaraki 305-8572, Japan \\ Author for correspondence: M. Asahina, asahina@nasu.bio.teikyo-u.ac.jp
}

\begin{abstract}
Summary: Laser microdissection (LMD), also called as Laser capture microdissection (LCM), is a method for isolating different tissue cells or specific single cells from wide variety of tissue samples under direct microscopic observation. LMD method enables to harvest the cells of interest region or specific cells for several analysis such as DNA/RNA analysis, proteomics, metabolomics and other molecular analysis. Currently, this approach can be used to study various biological events at tissue- or cellular-level, LMD has been used in the wide field of research. In this report, we describe techniques for isolation different tissues/specific cells from cryosections of Arabidopsis incised flowering stem by LMD for spatio-temporal gene expression analyses.
\end{abstract}

Key words: Arabidopsis thaliana, cryosection, gene expression analysis, laser microdissection, spatio-temporal analysis

はじめに

LMD (レーザーマイクロダイセクション)法とは，1990 年後半に開発された顕微鏡下で組織切片の必要な領域をレ 一ザーによって組織を一細胞レベルから回収する手法であ り, 生体の複雑な組織集合体を構成している一つ一つの細 胞の役割を解明するために利用されている (Emmert-Buck et al. 1996)。レーザーマイクロダイセクションによる組織 回収法には大きく分けて2種類が存在し，切片上の標的細 胞・組織に熱融解する特殊なフィルムを載せ，標的細胞に レーザーを照射することで切片をフィルムに粘着させるこ とで回収する Laser Capture法と, 標的細胞の周辺をレー ザーで切断し，標的細胞・組織を回収する Laser Cutting 法 とがある。いずれも顕微鏡下で組織を観察しながら標的部 位を回収できることに大きな利点があり，DNAやRNA， タンパク質の局在解析や組織特異的な解析に用いられてい る（高橋と中園 2006）。

LMD法は, 主に動物組織を用いた研究に利用され, 発 現解析の他, DNA, タンパク質, 代謝産物の解析なぞ, 多くの研究成果が報告されてきた。 また, 悪性腫瘍の遺伝
子診断等にも使用されている(野口 2001)。一方，植物材 料からの研究報告は, 動物分野に比べて乏しいのが現状で ある。なぜなら，植物細胞には細胞壁が存在しており，動 物細胞に比べて切片の作製やレーザーによる組織の回収が 困難であるからである。また，組織切片の作製には主に凍 結切片法やパラフィン切片法が用いられるが, 使用する植 物種・組織によって, 核酸の回収率や組織の形態保持に 大きな差が生じることも，LMD法で植物材料を使用する 際の大きな問題となっている。しかし近年では，植物に おいても LMD 応用した研究成果が報告されるようにな つている (Asano et al. 2002, Nakazono et al. 2003, Ishimaru et al. 2006, Toyomasu et al. 2015, Yamauchi et al. 2019). こ れらの多くは, 組織特異的な発現解析を目的としたcDNA ライブラリーの作成やマイクロアレイ解析であるが，プ ロテオーム解析やメタボローム解析の報告もされている (Hölscher and Schneider 2008, Falter et al. 2015). 近年では, 試料作製技術や分析機器の進歩や, 高感度検出手法の確立 によって検出に必要な材料が減り, これまで以上に多くの 試験区をより手軽に解析することが可能になってきている. 
これらのことから，様々な分野での応用が期待されてい るが，レーザーマイクロダイセクションを行うに当たって は目的に応じた試料作成法が特に重要とされる。

筆者らの研究グループでは, シロイヌナズナ切断花茥の 癒合を制御する遺伝子発現と植物ホルモンの時空間的変化 の解明を目的に研究を進めている (Asahina et al. 2011 なぞ). 本稿では我々が用いているレーザーマイクロダイセクショ ンを用いたシロイヌナズナ切断花茎の凍結切片からの遺伝 子解析と, 植物ホルモン解析に対する取り組みついて述心゙ ることとする。

\section{組織切片の準備}

レーザーマイクロダイセクションを行うに当たつては, まず組織切片を作成する必要がある。近年では，培養細胞 から目的の細胞や細胞塊を回収するアプリケーションや, 植物の葉などから組織を直接回収する取り組みも見られる が, 詳細は関連する文献等を参照していただきたい。

レーザーマイクロダイセクションに用いる組織切片には, 主に凍結切片とパラフィン切片が挙げられる（高橋と中園 2006)。凍結切片は，パラフィン切片作成のような煩雑な 作業が不要であり，比較的簡便に切片が作成できる。また， 核酸の回収効率が高く，二次代謝産物なぞの機器分析にも 速やかに使用できる利点がある。その一方，植物では凍結 の際に水結晶が生じやすく，植物種や組織によっては，形 態保持が困難な場合も見られる。一方，パラフィン切片は 組織の形態保持に優れているが, 組織切片作成にまとまつ た時間が必要であり，核酸の回収効率が凍結切片に比べて 低いことが多い，対象とする植物種，組織や目的に応じて 凍結切片とパラフィン切片を使い分けることが大切である。 本稿では, 我々が使用している凍結切片作成法について概 説する。

\section{組織の固定と包埋}

レーザーマイクロダイセクションに用いる組織切片の作 成には, 採取した組織を固定する必要がある. 組織の固定 法には化学固定法と物理固定法があり, 化学固定ではグル タールアルデヒドやホルムアルデヒドなどの還元剤，アセ トンやFarmer固定液等を用いることが多いが，ホルムア ルデヒドなどでは核酸を切断してしまうことがあるため, 核酸の抽出を目的とした場合には避けた方が良いとされる (LMD Sampling Manual Leica, 2018).

筆者らは，切片の作成には主に凍結による固定を行って いる。花茎などの組織の場合は, 採取した組織を直接液体 窒素中で凍結した後にOCT PSCEMなに゙の包埋剤に埋め 込み，ドライアイス冷却で泠却した $n$ ーヘキサンで急速凍 結させて凍結ブロックを作成し，切片の作成に用いる.

液体窒素凍結によって組織が著しく変形する場合や, 子 葉なぞ液体窒素による凍結によって組織が破損する危険性 がある場合には，採取した組織を凍結せずに包埋剤に埋め 込み, ドライアイス冷却へキサンで包埋剂を急速凍結させ, 凍結ブロックを作成している。凍結ブロックは， $-80^{\circ} \mathrm{C} て ゙$ 保存することが可能である.

OCT やSCEM な゙の包埋剂による凍結ブロック作成時 には，ドライアイスで邻した $n$ ーヘキサンを用いている. ヘキサンの代わりにイソペンタンを用いることもできる。
これらの溶媒は疎水性であり, 沸点と融点との差が大きい ことが利点である(堤と平澤 2004)。液体窒素では組織と の接触面で液体窒素が気化することによつて凍結速度が落 ちることがあるほか, 凍結過多によるブロックのひび割れ を起こすことがある。ディープフリーザーや凍結ミクロト 一ムの庫内で凍結させる方法もあるが，アーティファクト や氷晶が生じやすくなるため, 留意する必要がある.

\section{凍結切片の作製と LMDによる対象領域の回収}

凍結切片は, 川本法に従って凍結切片を作製している (図1)。ここでは, 我々が行っているシロイヌナズナ切断 花茎の凍結切片の作製と, LMDによる対象領域の回収の 手順について概説する. 川本法の詳細は, 関連する文献 (Kawamoto and Kawamoto 2014 なぞ) を参照されたい.

まず, SCEM 適切な大きさの包埋容器に入れ (図 1a), ドライアイス冷却へキサンで半分程度凍結させた後, サン プルを並び入れ (図 $1 \mathrm{~b}$ ), その上からさらにSCEM を入れ, 再び包埋容器全体を冷却させてSCEM を完全に凍結させ た (図1c). 包埋容器から凍結したブロックを取り出し(図 1d), 凍結ミクロトーム用のホルダに取り付けた (図 1e). ブロックをトリミングしてサンプルを露出させた後, 専用 の川本法フィルム (SECTION-LAB) を用いて切片を作製し た. 作成した切片は, 凍結ミクロトーム内で 30 分以上凍 結乾燥させたのち, $-80^{\circ} \mathrm{C} て ゙$ 保存した。

凍結切片からの対象領域の回収は, ライカ社のレー ザーマイクロダイセクション装置 (LMD 7000, Leica Microsystems) 老用いて行っている。デシケーター内でサ ンプルを常温に戻し，専用の金属フレームに張り替えてか ら切片回収に用いる(図1f).

一般的に, 切片から組織を回収する際には, トルイジン ブルーなどによる染色走行うことが多い。染色によって組 織の観察が容易になるだけでなく、レーザーの吸収効率が あがり, 組織の切断が良くなるとされる。しかし, 筆者ら が同じ組織から作成した連続切片を用いてトルイジンブル 一染色の有無によるRNA抽出効率支比較したところ, 染 色を行った切片では, 最大で7割ほぞRNAの回収率が低 下していた。無染色切片を用いる場合には切片の観察が難 しくなることが多く，またレーザーパワーや apertureなど を調節する必要があり，切断による切片のロスが大きくな ることがある。そのため, 新しい植物種や組織を用いて実 験を行う際には, まずは染色切片と無染色切片の両者を作 成し, 染色切片において用いて組織の形態が十分に保持さ れていることを確認した後, 試験的にDNA/RNAを抽出し, 無染色切片と抽出効率や純度を比較すると良い. LMDに よって回収できる核酸は極微量であるため, 染色切片にお いて核酸の抽出効率が著しく低下している場合には, 無染 色切片を用いた回収法を検討することが望ましい.

いずれの場合においても, 形態の判別やRNAの抽出効 率に応じて, 適切な染色方法を判断する. 蛍光観察や微分 干渉観察, 暗視野観察なぞが可能な場合には, 観察条件も 検討すると良いだろう。

遺伝子発現解析の場合, 回収した組織は, buffer RLT に $1 / 100$ 量の $\beta$-メルカプトエタノールを加えた抽出バッファ 一を約 $50 \mu \mathrm{L}$ 分注したマイクロチューブの蓋に回収する. 回収した組織は, 浸漬させた状態で $-80^{\circ} \mathrm{C} に て$ 保存し, 市 
a

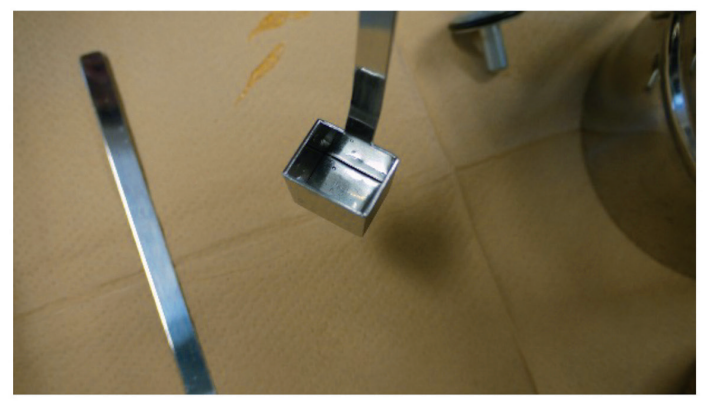

C

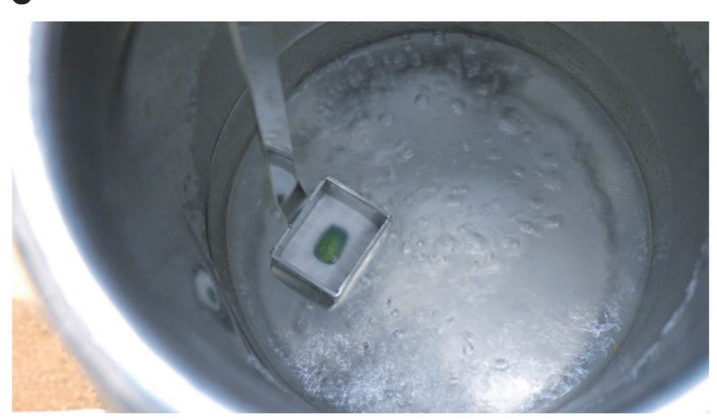

e

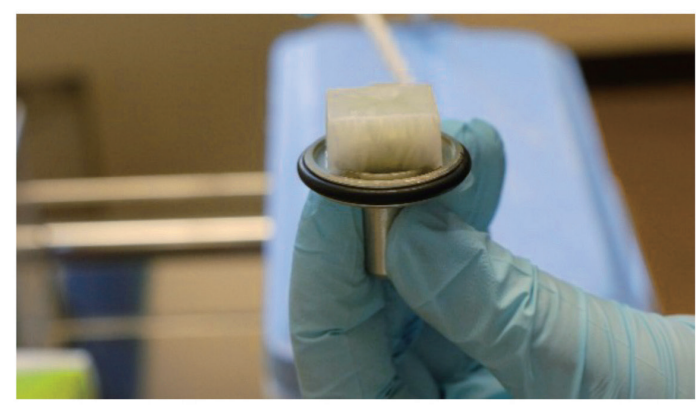

b

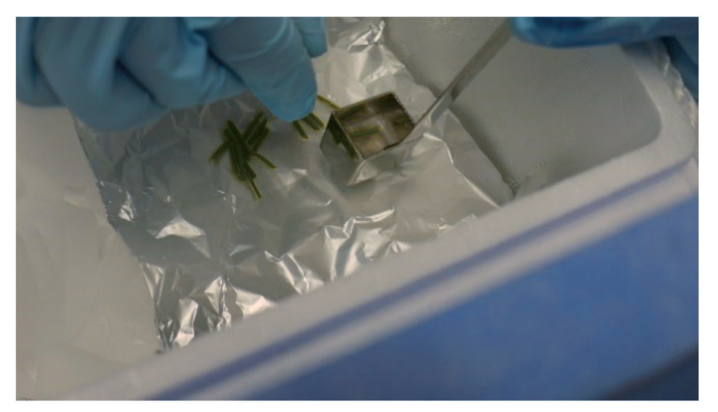

d

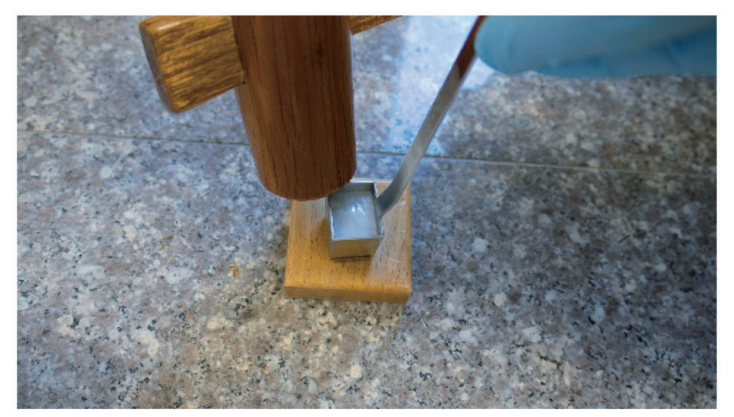

f

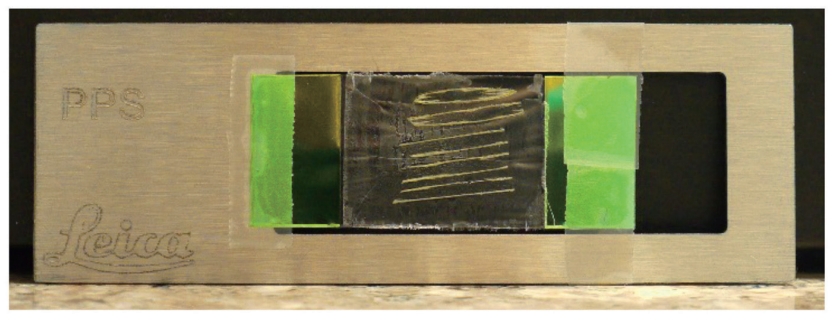

図 1 凍結切片の作製工程. (a) 使用する包埋容器. (b) SCEMにサンプルを包埋. (c) ドライアイス冷却ヘキサンで包埋剂を凍結させ，ブ ロックを作成. (d) 完全に凍結したSCEM を包埋容器から取り出す. (e) 取り出したSCEM を凍結ミクロトームの土台に固定. (f)川本法に て作成した切片を，フィルムごとステンレスフレームに固定.

販の抽出キット (RNeasy Micro Kit, QIAGEN) を用いて, RNA 抽出を行う.

図 2 は, 我々が行つているシロイヌナズナ切断花茎から の組織別回収の工程である。切片の厚さは $15 \mu \mathrm{m}$ であり, 染色は行っていない，組織によって面積あたりの細胞数 が異なるため一概に比較はできないが, 我々の条件では, $100 \mathrm{ng}$ のトータルRNA を抽出するためには, 合計で約 20$100 \mathrm{~mm}^{2}$ の組織切片が必要であった。組織の回収には時間 を要するため, LMDで組織の回収を行う前にまず微量の 凍結切片や凍結試料から試験的にトータルRNA を抽出し, 収量を概算することが望ましい。

抽出したRNAは, PrimeScript ${ }^{\mathrm{TM}} \mathrm{RT}$ reagent Kit with gDNA Eraser (タカラバイオ) を用いて逆転写反応を行い, リアルタイムPCRを用いた遺伝子発現解析に用いている. この他, マイクロアレイやRNA-seq等によるトランスク リプトーム解析にも使用している (未発表). 現在では, 様々
なメーカーから，極微量 RNAからの遺伝子発現解析キッ 卜が販売されており，目的に応じて使い分けると良いだろ う.

また，筆者らの研究グループでは，LC-MS/MS を用い た植物ホルモンの機器分析にも取り組んでいる。回収に 用いる抽出溶媒や解析に用いる組織量は異なるが，凍結 切片の作成法やLMDの条件などは基本的に同じである. LC-MS/MS 解析の場合, LMDによって切断した組織は $50 \%$ メノール溶液に回収し，その後，終濃度が $80 \%$ に なるようにメタノールを添加して植物ホルモンを抽出して いる.

このように, LMDにより単離した組織はプロテオーム やメタボローム解析など, 様々な応用が期待できる、今後, 遺伝子解析法や機器分析法のさらなる発展によって, 細胞・ 組織レベルでの精度の高い解析が可能となるだろう。 
a

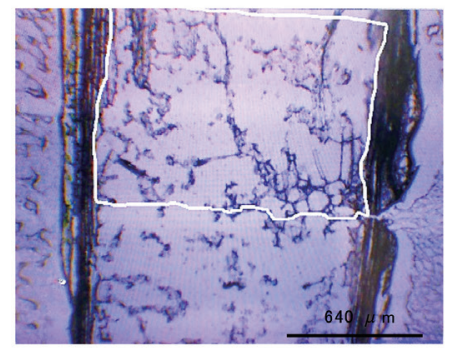

C

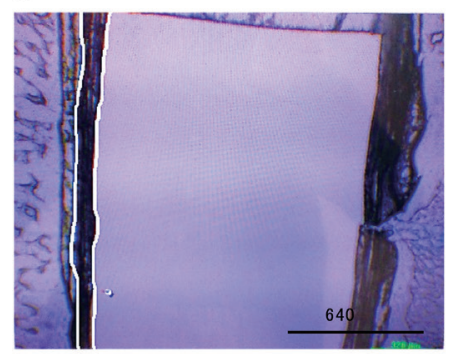

e

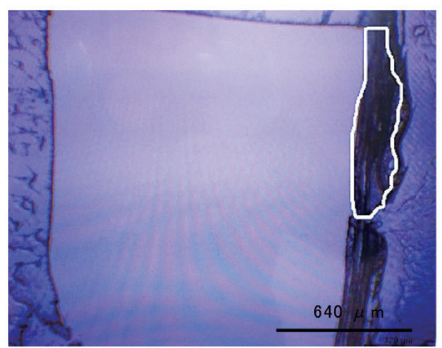

g

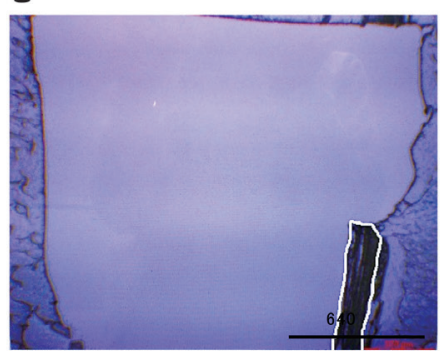

i

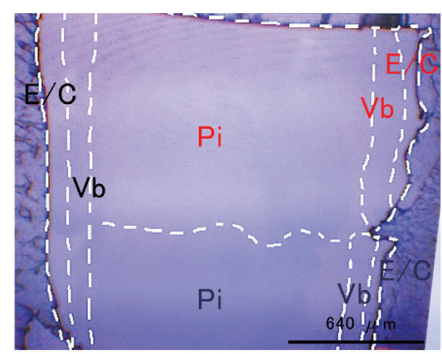

b

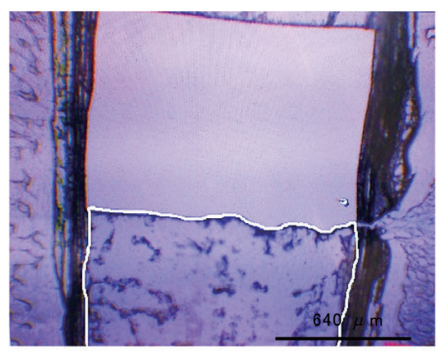

d
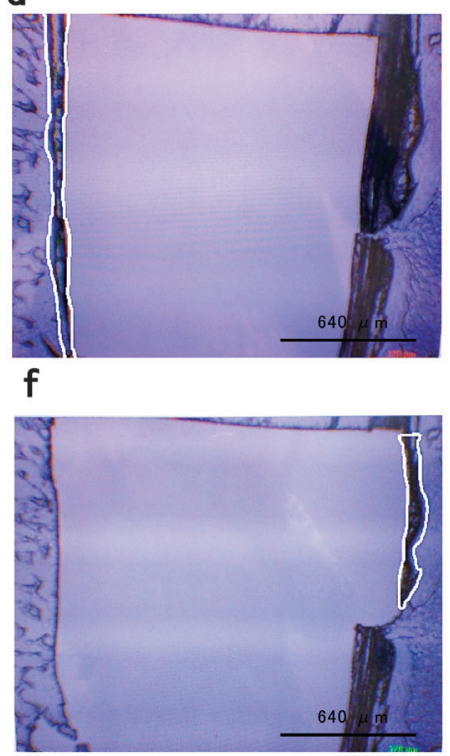

h

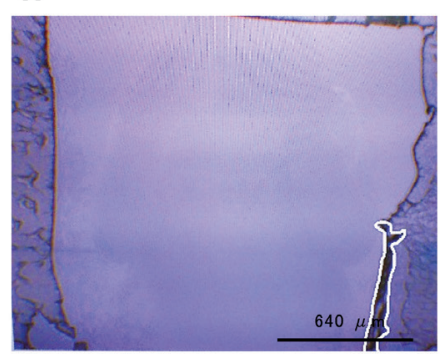

図2 シロイヌナズナ切断花茥 (Asahina et al. 2011) の凍結切片からの組織別回収. 切断花茥の縦切り切 片は, 傷側と無傷側領域に分け，傷側の組織は，表 皮・皮層 (Epidermis/ Cortex; E/C), 維管束 (Vascular bundle; Vb), 髄 (Pith; Pi) に区別し,さらに傷上部 と下部領域に分けて回収した。無傷側 (Non-incised face; N)の組織は, 表皮・皮層 $(\mathrm{E} / \mathrm{C})$, 維管束 $(\mathrm{Vb})$ に分けて回収した。 スケールバーは $640 \mu \mathrm{m}$. 染色 は行っていない.

\section{謝辞}

本研究の遂行にあたり，ご協力をいただきました帝京大 学理工学部バイオサイエンス学科の山根久和教授, 横田孝 雄名誉教授, 松岡啓太博士, 柴田恭美さんに厚く御礼申し 上げます。また，レーザーマイクロダイセクションに関す る実験を行ってくれた卒研生の島田菜美さん, 名城やよい さん, 仁平彩也香さん, 小倉健太朗さん, 伴瀬真麻さん, 野田幸男さん，小池龍一さん，インドネシア・アトマジャ
ヤ大学からの短期留学生 Benedictus Harvianさん, Marini Putri Pranataさん, Fedho Kusumaさんに感謝いたします。 本研究の一部は, 科学研究補助金 (16K18572, 19K06728), 私立大学戦略的研究基盤形成支援事業・植物オキシリピン の生理機能の解明とその応用 (S1311014), 私立大学等経常 費補助金 (大学間連携等による共同研究) の支援を受けて 行いました。 


\section{引用文献}

Asahina M., Azuma K., Pitaksaringkarn W., Yamazaki T., Mitsuda N., Ohme-Takagi M., Yamaguchi S., Kamiya Y., Okada K., Nishimura T., Koshiba T., Yokota T., Kamada H., and Satoh S. (2011) Spatially selective hormonal control of RAP2.6L and ANAC071 transcription factors involved in tissue reunion in Arabidopsis. Proc Natl Acad Sci USA 108: 16128-16132.

Asano T., Masumura T., Kusano H., Kikuchi S., Kurita A., Shimada H., and Kadowaki K. (2002) Construction of a specialized cDNA library from plant cells isolated by laser capture microdissection: toward comprehensive analysis of the genes expressed in the rice phloem. Plant J 32: 401-408.

Emmert-Buck M. R., Bonner R. F., Smith P. D., Chuaqui R.F., Zhuang Z., Goldstein S. R., Weiss R.A., and Liotta L. A. (1996) Laser capture microdissection. Science 274: 9981001.

Falter C., Ellinger D., von Hülsen B., Heim R, and Voigt C. A. (2015) Simple preparation of plant epidermal tissue for laser microdissection and downstream quantitative proteome and carbohydrate analysis. Front Plant Sci 2015 6:194.

Hölscher D., and Schneider B. (2008) Application of laserassisted microdissection for tissue and cell-specific analysis of RNA, proteins, and metabolites. In: Lüttge U., Beyschlag W., and Murata J. (eds) Progress in botany. vol 69. Springer, Berlin, Heidelberg.

Ishimaru Y., Suzuki M., Tsukamoto T., Suzuki K., Nakazono M., Kobayashi T., Wada Y., Watanabe S., Matsuhashi S., Takahashi M., Nakanishi H., Mori S, and Nishizawa N.K. (2006) Rice plants take up iron as an $\mathrm{Fe}^{3+}$-phytosiderophore and as $\mathrm{Fe}^{2+}$. Plant J 45: 335-346.

Kawamoto T., and Kawamoto K. (2014) Preparation of thin frozen sections from nonfixed and undecalcified hard tissues using Kawamoto's film method (2012). Method Mol Biol 1130: 149-164.

Nakazono M., Qiu F., Borsuk L. A., and Schnable P. S. (2003) Laser-capture microdissection, a tool for the global analysis of gene expression in specific plant cell types: identification of genes expressed differentially in epidermal cells or vascular tissues of maize. Plant Cell 15: 583-596.

Toyomasu T., Usui M., Sugawara C., Kanno Y., Sakai A., Takahashi H., Nakazono M., Kuroda M., Miyamoto K., Morimoto Y., Mitsuhashi W., Okada K., Yamaguchi S., and Yamane H. (2015) Transcripts of two ent-copalyl diphosphate synthase genes differentially localize in rice plants according to their distinct biological roles. $J$ Exp Bot 66: 369-376.

Yamauchi T., Tanaka A., Inahashi H., Nishizawa N.K., Tsutsumi N., Inukai Y., and Nakazono M. (2019) Fine control of aerenchyma and lateral root development through AUX/IAA and ARF-dependent auxin signaling. Proc Natl Acad Sci USA 116: 20770-20775.

野口雅之 (2001) マイクロダイセクション法と遺伝子診断, 順天堂医学 46: 416-422.

高橋宏和, 中園幹生 (2006) 作物の形態研究法 : マクロか
らミクロまで レーザーマイクロダイセクション法,

日本作物学会紀事 75: 583-585.

堤寬, 平澤浩 (2004) 新鮮凍結切片のつくり方, 病理と臨 床 22: 515-518

Received: 13 December 2019 / Accepted: 29 February 2020 